\title{
A Model of Organizational Culture for Enhancing Organizational Commitment in Telecom Industry: Evidence from Vietnam
}

\author{
HA NAM KHANH GIAO ${ }^{1}$, BUI NHAT VUONG ${ }^{*}$, DAO DUY TUNG ${ }^{2}$ \\ ${ }^{1}$ Faculty of Air Transport, Vietnam Aviation Academy, Ho Chi Minh, VIETNAM \\ ${ }^{2}$ Graduate School of Management, Siam University, Bangkok, THAILAND \\ *Corresponding author: nhatvuonga1@gmail.com
}

\begin{abstract}
The aim of this study is to investigate the influence of organizational culture on organizational commitment in the context of the Vietnam telecom industry. The model was tested with a sample of 324 employees working for telecom companies. The result from the partial least squares method (PLS) using SmartPLS 3.0 program revealed a good fit between collected data and measurement scales which were introduced and developed in the Western contexts. Besides, the findings showed that the six dimensions of organizational culture had positive impacts on organizational commitment decreasingly: innovativeness, teamwork, training and development, reward and recognition, organizational communication, empowerment. This discovery highlighted the importance of organizational culture in enhancing employee commitment towards the organization as well as calls the management attention to these dimensions and long-term development policies.
\end{abstract}

Keywords: organizational culture, employee commitment, innovativeness, teamwork, training and development, organizational communication, empowerment

\section{Introduction}

Vietnam's economy has recently developed rapidly with the strong growth of domestic companies. Most of the companies have not formed separate business characters. Economic integration offers many opportunities but also challenges in the fiercely competitive environment, more intense. In the context of globalization, besides interference such as human resources, equipment, machinery, work methods, etc... There is an exchange between cultural diversity, affecting the style and attitude of the business and the handling of this relationship is extremely complex. The interests of people also moved to focus on cultural values. Competition by technology, capital, and resources in an era of a flat world is no longer maintained by the long-term nature of its rapid diffusion. People start caring about human resource and see human resource is a valuable asset, it needs to be invested and developed to promote innovation, keep a competitive advantage through the development of corporate culture. Unlike technology, organizational culture is difficult or impossible to imitate from other corporate environments, it will create its definition, depending on each specific region, attracting business. However, all building activities of organizational culture are still highly formalistic, not pay proper attention, many companies have not realized the important role of the building of cultural identity in business, and have not seen the organizational culture as the foundation and driving force of business development. Over the past few decades, organizational culture has been an important topic in business management research because it affects organizational and personal aspects such as commitment, loyalty, and satisfaction of employees at work. Organizational culture is considered a management philosophy, the way organizations manage to improve the performance of their work as well as the ability to influence the thoughts, emotions and organizational communication.

In this context, the study of organizational culture and its influence in the survival and development of companies carry important significations, especially in the raising business of the Vietnam corporate today in general and telecom companies in particular. After a period of development, in order to timely adapt to changes in the business environment. Telecom corporations have been conducting a comprehensive restructuring. The process of organizational restructuring, the change of the working apparatus, the way of working, organization culture, has led to significant changes in the employees' intention to leave their organization. Memari, et al. [1] stated that organizational commitment is an antecedent of job performance, intention to leave, lateness and turnover. It plays an important role to prevent the potential risk of human resource management. Through many years of struggling against employees' jumping, organizations have well acknowledged the risk of shifting 
employees and the role of employees' commitment in the current competitive environment. In this regard, they start paying attention to a key antecedence as organizational culture. Besides, some scholars [e.g., 2,3] explored that firms that have an organizational culture in the workplace have a more engaged workforce. Therefore, the study of organizational culture at telecom companies which is conducted to determine the impact on organizational commitment is very necessary.

\section{Literature Review}

\subsection{Organizational Culture}

There are different definitions of culture, each defining a different way of seeing and evaluating. According to UNESCO: "Culture is that complex whole which includes knowledge, beliefs, arts, morals, laws, customs, and any other capabilities and habits acquired by a human as a member of society". Some definitions of organizational culture: organizational culture are symbols, languages, ideologies, rituals, and myths [4]. Schein [5] defined that "organizational culture is defined by norms, values and common assumptions". Organizational culture is the key to superior business and the function of leadership is to create and manage culture. Experienced leaders and researchers in the area of corporate strategy and development have suggested that the examination of cultural issues at the enterprise level is necessary [5].

Organizational culture has attracted the attention of human resource managers, especially in the past three decades. There has been a great deal of research done on this area and also many organizational culture models are presented in many studies [e.g., 6,7,8]. Additionally, Boon and Arumugam [2] have established the scope of organizational culture consists of four dimensions including training and development, reward and recognition, organizational communication, teamwork. The authors selected this model as the basis for researching Telecom companies, as verified to have a significant impact on employee behavior and attitude in many Asian countries. Moreover, the result of qualitative research added two dimensions of organizational culture such as "Innovativeness" and "Empowerment" in the research model at Telecom companies in Vietnam.

\subsection{Organizational Commitment}

Organizational commitment is a long-term commitment to the organization, so organizations often try to push their employees' commitment higher to achieve stability and reduce costs. Employees who highly commit to an organization will work harder to achieve their goals. According to Porter, et al. [9], organizational commitment is described by the intention to remain in the organization, in agreement with the organization's values and goals. Organizational commitment is the power of individual unity with the organization and active participation in the organization; Employees with a high level of commitment with the organization will be more satisfied with their work, less likely to leave work [1]. Bateman and Strasser [10] stated that organizational commitment is a multi-dimensional relationship in nature, involving employee loyalty to the organization, willingness to work for the organization, level of purpose and legitimate value to the organization, and the desire to remain with the organization. Thus, organizational commitment is a psychological state that implies the attachment of an individual to an organization.

This study employs the three-component model of Meyer and Allen [11] to examine the telecom employees' commitment to the telecom companies they are working for. The three-component model which was re-conceptualized from numerous definitions has been broadly used in the academic community thanks to its widespread application in various domains, accordingly, the organizational commitment was classified by three distinguishable mindsets: "affective commitment", "continuance commitment" and "normative commitment". Firstly, affective commitment refers to emotionally attached, consensual and drawn into the organization. Secondly, continuance commitment reflects a sticking to the fact that employees find high costs (opportunity costs) to leave the organization. Lastly, normative commitment reflects a feeling obliged to continue the work. Among the three components of commitment, and affective commitment was found to be the most important factor compared to continuance commitment and normative commitment [12]. This can be explained by the argument that staffs tend to make their own decision on whether they would like to remain with an organization (affective commitment) rather than they do so for obligation (normative commitment) or financial issues (continuance commitment). Once an employee's emotional bond to their workplace no longer exists, they tend to leave for another job instead of staying for any other purposes. For this reason, the study concentrates on affective assessment to interpret the organizational cultureorganizational commitment connection. 


\section{Hypotheses}

\subsection{Organizational Communication}

Dwyer [13] stated that "communication is necessary for passing information between people working in the same company and between the company and other organizations. Communication includes written, oral and nonverbal. Communication is used by management to direct and motivate employees and to evaluate their performance. Regular information exchanges will help employees to understand the goals, strategies of the business, and the success of the business that derives from their contributions. In addition to, the regular working in the business always need information and exchange between staffs, with the purpose of strengthening exchanges, the staffs can comment straightforwardly in all matters in each specific field of activity; when they exchange together, the information is shared, so the work goes smoothly. Thereby affecting employee commitment. Similarly, some previous researchers examined and found that organizational communication has a positive effect on employee commitment [e.g., 14]. Therefore, the following hypothesis is posited:

$\mathrm{H}_{1}$ : Organizational communication positively influences organizational commitment.

\subsection{Teamwork}

Scarnati [15] defined teamwork as "a cooperative process that allows ordinary people to achieve extraordinary results". They share knowledge, skills, and ideas between members to solve problems and get a better result. In the field of telecommunications, every job he is catering to a certain project. Almost all projects have to undergo multiple parts at the same time, requiring cooperation to work closely together for a project to be implemented effectively. For that reason, teamwork is a very important property in the execution of work and affects all employees in the work process. Some studies have examined the link between teamwork and organizational commitment $[2,16]$. In summary, a review of the literature finds that teamwork plays an important role in motivating employees and hence provides high commitment towards an organization. Therefore, the following hypothesis is posited:

$\mathrm{H}_{2}$ : Teamwork positively impacts organizational commitment.

\subsection{Training and Development}

Bulut and Culha [17] defined training and development as "systematic activities to develop and improve employees' skills, knowledge and behaviors to enable them to perform job-related duties, accomplish specific tasks and meet the quality requirements of human resources for the future". Moreover, training and development are the processes of improving worker's capacity through education to make they are able to perform their work more effectively to meet the current requirements of the organization. This is a particularly important matter because of industryspecific barriers in this area too large. An equipped with the knowledge and skills of employees is fully required so that they can be confident in their work and thereby brings the highest possible efficiency and achieve individual development.

When training and development are certainly meeting of organizational needs and personal needs, staffs tend to be more committed. They will be active and dynamic at work when they are fully qualified, capable and well-trained, it also increases commitment. Some previous researchers found that training and development has a positive impact on employee commitment [e.g., 16,18]. Basing on the arguments above, the following hypothesis is posited: $\mathrm{H}_{3}$ : Training and development positively impact organizational commitment.

\subsection{Reward and Recognition}

Juran and Gryna [19] defined reward and recognition as "benefits as increased salary, bonuses, and promotion, which are conferred as a public acknowledgment of superior performance with respect to the company's objectives". Reward is always a difficult issue in society and within the enterprise. There is no perfect reward policy and can be applied absolutely to all organizations and employees. Rewards must be consistent with corporate culture. It contains the contradictory relationship between workers' expectations and the company's ability, between accumulation and consumption, the income of other positions. At a certain level, reward can be considered as evidence to show the value, position, prestige of employees for personal and social. Moreover, recognition is one of the most factors which can't be lacked in a rewards management system. It is considered as "esteem needs" in the hierarchy of Maslow's need theory. Joinson [20] argued that cash awards are good, but they are not very effective in the long-term, because many people want to be respected and valued for their contribution. The organizations, therefore, should enhance their employee commitment by offering financial as well as nonfinancial benefits.

Also, it is expected that employees are more likely to commit themselves at work whenever they can receive a greater amount of reward and recognition 
for their work. With these arguments, it can assume that appropriate recognition and rewards are important for commitment. Moreover, some prior researchers demonstrated that there was a positive relationship between reward and recognition and employee commitment [e.g., 18,21]. Thus, the study proposes the hypothesis as follow:

$\mathrm{H}_{4}$ : Reward and recognition positively impact organizational commitment.

\subsection{Innovativeness}

West and Farr [22] defined that innovativeness is known as "the intentional creation, introduction, and application of new ideas within a work role, group or organization, in order to benefit role performance, the group, or the organization". Innovativeness is direct and intention-behavior to change something in a way of creating different conditions with the current situation at the time. According to Grant and Berry [23], innovativeness is considered a very crucial factor for the survival of an organization due to its benefit to the organization. It enables an organization's adjustment to take advantage of emerging opportunities. Due to the characteristic of the telecom work role, employees are often passive to do follow by the available procedures. They lack innovativeness when dealing with customers' problems. Therefore, this study assumes that innovativeness will help telecom employees to be more innovation, confidence, and commitment in their work behavior when offering a telecom service to the customer. Moreover, Inanlou and Ahn [6] and Vuong and Suntrayuth [24] justified that an innovative culture has a strong positive relationship with employee commitment. Basing on the arguments above, the following hypothesis is posited: $H_{5}$ : Innovativeness positively impact organizational commitment.

\subsection{Empowerment}

Page and Czuba [25] defined empowerment as social stages of a process that supports people get control over themselves. Further, it has been revealed that the manager's power and control sharing with subordinates would be very productive forms of organizational power and effectiveness. Nevertheless, empowerment is a very general concept and a number of researchers have argued that it is not about management practices or structural sharing power, but it should be about the individual psychological experience of empowerment. Moreover, some researchers find that subordinates' internal behaviors which firstly help employees to perceive themselves as being empowered would be the true benefits of empowerment. According to expectancy theory, a motivation to increase subordinate's effort to fulfill a given task would lead to the expected performance and that expected performance would lead to employee commitment. In the research of Hanaysha [16] and Giao and Vương [26] found that empowerment had a positive relationship to employee commitment. Basing on the arguments above, the following hypothesis is posited: $H_{6}$ : Empowerment positively impact organizational commitment.

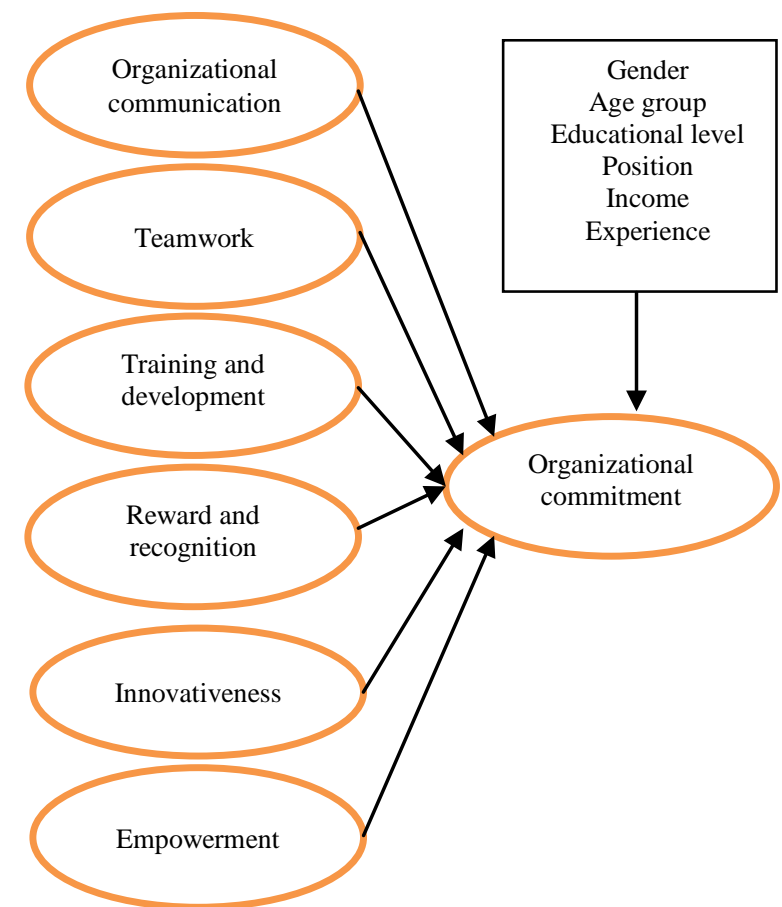

Fig.1. The conceptual model

\section{Research Methodology}

\subsection{Procedure and sample}

Respondents were employees who were working at the telecom companies in Vietnam. First of all, we collected a list of telecom companies in Vietnam. We chose telecom companies in both the South and North area in Vietnam because almost telecom companies were placed in these areas. Using a convenience method, we chose around 41 companies to do the survey. When we had a collected company list to do the survey, the authors called to the companies to collect data of the person in charge human resource manager. We explained clearly about our topic and purpose to do this survey. Totally, 27 companies advised the information to us.

Based on the previous studies, the authors finished the draft questionnaire. The draft questionnaire was originally developed in the English language, authors translated the questions into the Vietnamese 
language, and authors then performed the backtranslation with the support of several English language experts.

After finished the main questionnaire, we designed the questionnaire on Google Docs and hard copy. It had to easy to read, to stick and sent back to us. The questionnaires were distributed to 27 firms in the chosen sample. About 292 completed questionnaires were collected via Google Docs and 56 questionnaires collected directly. Among these, 24 questionnaires were found invalid due to the respondents answered one choice for the total questions. Consequently, there were 324 valid feedbacks usable for further data analysis. Table 1 below showed the demographic profile of respondents.

Table 1. Demographic characteristic

\begin{tabular}{|c|c|c|c|}
\hline \multicolumn{2}{|r|}{$\mathrm{N}=324$} & Frequency & Percent \\
\hline \multirow{2}{*}{ Gender } & Female & 131 & 40.4 \\
\hline & Male & 193 & 59.6 \\
\hline \multirow{4}{*}{ Age group } & $18-25$ & 101 & 31.2 \\
\hline & $26-35$ & 168 & 51.9 \\
\hline & $31-45$ & 36 & 11.1 \\
\hline & $>45$ & 19 & 5.9 \\
\hline \multirow{4}{*}{ Income } & $<5$ million VND & 39 & 12.0 \\
\hline & 5-10 million VND & 185 & 57.1 \\
\hline & 10-15 million VND & 52 & 16.0 \\
\hline & $>15$ million VND & 48 & 14.8 \\
\hline \multirow{4}{*}{ Education } & Under college & 56 & 17.3 \\
\hline & College & 104 & 32.1 \\
\hline & University & 138 & 42.6 \\
\hline & Postgraduate & 26 & 8.0 \\
\hline \multirow{4}{*}{ Experience } & Under 1 year & 88 & 27.2 \\
\hline & 1 -2 years & 100 & 30.9 \\
\hline & $2-5$ years & 59 & 18.2 \\
\hline & Above 5 years & 77 & 23.8 \\
\hline \multirow{2}{*}{ Position } & Employee & 276 & 85.2 \\
\hline & Manager & 48 & 14.8 \\
\hline
\end{tabular}

\subsection{Variable Measurements}

All the variables in the model were measured with multiple items, each item was scored on a five-point scale examining how strongly respondents agree or disagree with the statement, with $1=$ "strongly disagree" and 5 = "strongly agree", which developed by prior researchers. Specifically, organizational communication, teamwork, training and development, reward and recognition scales were measured by 16 items of Boon and Arumugam [2]. Sample items included (Organizational communication: e.g., "The company employees' communication is effective in communicating things that are relevant to them"); (Teamwork: e.g., "Work within this department is appointed around groups"); (Training and development: e.g., "Resources are available for employees' education and training within the company"); (Reward and recognition: e.g., "Reward and Recognition system within the company rewards relationship and task accomplishments based on work quality"). Innovativeness and empowerment scales were measured by 9 items of Denison and Mishra [27]. Sample items included (Innovativeness: e.g., "People are encouraged to be creative"); (Empowerment: e.g., "Everyone believes that he or she can have a positive impact"). Affective commitment scale was measured by 5 items of Meyer and Allen [11]. A sample item included (e.g., "I would be very happy to spend the rest of my career with this organization").

\subsection{Partial Least Squares Regression}

Giao and Vuong [28] suggested that the partial least square-structural equation modeling (PLSSEM) via the SmartPLS program should be used to test hypotheses due to the data doesn't require to be normally distributed. Thus, the authors employed the SmartPLS 3.0 to analyze data in this study.

\section{Research Result}

\subsection{Reliability and Validity of Scales}

According to Vuong, et al. [29], the reliability for all of the latent variables should be assessed by using composite reliability (CR). Giao, et al. [30] posited that a score of CR is at least 0.7 to say that a measure is internally consistent. As shown in Table 2 below, the composite reliability score for each of the constructs was greater than 0.7. For example, the minimum CR of the variables was 0.865 . Therefore, it demonstrated good internal consistency reliability.

On the other hand, Giao and Vuong [28] stated that the average variance extracted (AVE) scores should be used to assess the convergent validity of the latent variables. Convergent validity will be confirmed when AVE for each of the constructs is higher than 0.5. As shown in Table 2 below, the minimum AVE score for all of the variables was 0.564 , which was higher than 0.5 . Thus, each of the constructs indicated good convergent validity.

Discriminant validity indicates the uniqueness or distinctness of a construct when compared to others in the model. Giao and Vuong [28] recommended that discriminant validity is found when the square root of AVE for each of latent variables is higher than other correlation values among any other construct. As shown in Table 2, this analysis shows (in bold) that adequate discriminant validity has been 
achieved by the square roots of the AVEs that were higher than the off-diagonal correlations.

According to Vuong and Giao [31], collinearity issues exist between respective exogenous variables and the endogenous variable. If the variance inflation factor (VIF) value is greater than 5, there are collinearity issues with the latent variables. In this study, the maximum value of VIF was 2.788. which was less than 5 . Thus, the latent variables did not have multicollinearity.

Table 2. Reliability and validity of constructs

\begin{tabular}{|c|c|c|c|c|c|c|c|c|c|}
\hline & CR & AVE & OC & CO & EM & IN & RE & TE & TR \\
\hline OC & 0.900 & 0.646 & 0.804 & & & & & & \\
\hline CO & 0.894 & 0.678 & 0.535 & 0.824 & & & & & \\
\hline EM & 0.865 & 0.564 & $\begin{array}{c}- \\
0.392\end{array}$ & $\begin{array}{c}- \\
0.592\end{array}$ & 0.751 & & & & \\
\hline IN & 0.903 & 0.701 & 0.536 & 0.640 & 0.522 & 0.837 & & & \\
\hline RE & 0.903 & 0.699 & 0.571 & 0.680 & $\begin{array}{c}- \\
0.589\end{array}$ & 0.571 & 0.836 & & \\
\hline TE & 0.897 & 0.686 & 0.526 & 0.517 & $\begin{array}{c}- \\
0.597\end{array}$ & 0.449 & 0.685 & 0.828 & \\
\hline TR & 0.903 & 0.700 & 0.511 & 0.500 & $\begin{array}{c}- \\
0.524\end{array}$ & 0.481 & 0.597 & 0.588 & 0.836 \\
\hline \multicolumn{10}{|c|}{$\begin{array}{l}\text { Notes: } \\
\text { The diagonal (in bold) shows the square roots of the AVE } \\
\text { CR = Composite Reliability; AVE = Average Variance Extracted. } \\
\text { OC = organizational commitment; CO = organizational communication; EM = empowerment. } \\
\text { IN = innovativeness; RE = reward and recognition; TR = training and development. } \\
\text { TE = teamwork. }\end{array}$} \\
\hline
\end{tabular}

\subsection{Hypotheses Verification}

The structural model path coefficients assessment of the model was carried on employing the bootstrapping procedure.

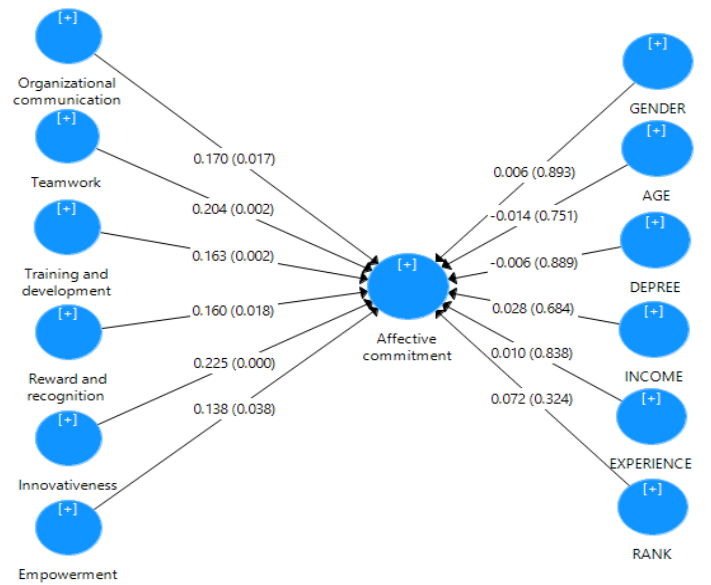

Fig.2. The PLS model

Most of all the relationships had meaning with the significant meaning (p-value $<5 \%$ ) in Table 3 as shown below:

For hypothesis 1, the result found that organizational communication had a positive impact on affective commitment with a standardized coefficient of 0.170 and $p$-value $=0.017$. The result of this study was consistent with the findings of the previous study of Marchalina and Ahmad [14]. Therefore, hypothesis $\mathrm{H}_{1}$ was supported.
For hypothesis 2, the result found that teamwork had a positive impact on affective commitment with a standardized coefficient of 0.204 and p-value = 0.007 . Teamwork is always promoted by the nature of work that requires the effective collaboration of all members; effective teamwork will bring success to projects while also bringing the excitement of the staff to the job they are assigned. The result of this study was consistent with the findings of the previous study of Boon and Arumugam [2], Hanaysha [16]. Therefore, hypothesis $\mathrm{H}_{2}$ was supported.

Table 3. The result of the model

\begin{tabular}{|c|c|c|c|c|c|c|}
\hline Hypothesis & \multicolumn{3}{|c|}{ Relationship } & \multirow{2}{*}{\begin{tabular}{|c|} 
Std. \\
Beta
\end{tabular}} & \multirow{2}{*}{$\begin{array}{c}\begin{array}{c}\text { P- } \\
\text { value }\end{array} \\
0.017\end{array}$} & \multirow{2}{*}{$\begin{array}{c}\text { Result } \\
\text { Significant }\end{array}$} \\
\hline $\mathrm{H}_{1}$ & $\mathrm{CO}$ & $\rightarrow$ & OC & & & \\
\hline $\mathrm{H}_{2}$ & $\mathrm{TE}$ & $\rightarrow$ & OC & 0.204 & 0.002 & Significant \\
\hline $\mathrm{H}_{3}$ & TR & $\rightarrow$ & OC & 0.163 & 0.002 & Significant \\
\hline $\mathrm{H}_{4}$ & $\mathrm{RE}$ & $\rightarrow$ & OC & 0.160 & 0.018 & Significant \\
\hline $\mathrm{H}_{5}$ & IN & $\rightarrow$ & OC & 0.225 & 0.000 & Significant \\
\hline $\mathrm{H}_{6}$ & EM & $\rightarrow$ & OC & 0.138 & 0.038 & Significant \\
\hline \multicolumn{7}{|c|}{ Control variables } \\
\hline & Gen & $\rightarrow$ & OC & 0.006 & 0.893 & \\
\hline & Age & $\rightarrow$ & OC & -0.014 & 0.751 & \\
\hline & Deg & $\rightarrow$ & OC & -0.006 & 0.889 & \\
\hline & Inc & $\rightarrow$ & OC & 0.028 & 0.684 & \\
\hline & Exp & $\rightarrow$ & OC & 0.010 & 0.838 & \\
\hline & Pos & $\rightarrow$ & OC & 0.072 & 0.324 & \\
\hline \multicolumn{7}{|c|}{$\begin{array}{l}\text { Notes: } \\
\mathrm{OC}=\text { organizational commitment; } \mathrm{CO}=\text { organizational communication. } \\
\mathrm{EM}=\text { empowerment; } \mathrm{IN}=\text { innovativeness; } \mathrm{RE}=\text { reward and recognition. } \\
\mathrm{TR}=\text { training and development; } \mathrm{TE}=\text { teamwork; Gen = gender; Deg = degree } \\
\text { level. } \\
\text { Inc = income; Exp = experience; } \text { Pos = position. }\end{array}$} \\
\hline
\end{tabular}

For hypothesis 3, the research found that training and development had a positive impact on affective commitment with a standardized coefficient of 0.163 and p-value $=0.002$. Good training and development make the level of staff commitment higher. The result of this study was consistent with the findings of the previous study of Hanaysha [16] and Jaworski, Ravichandran, Karpinski and Singh [18]. Therefore, hypothesis $\mathrm{H}_{3}$ was supported.

For hypothesis 4, the research found that reward and recognition had a positive impact on affective commitment with a standardized coefficient of 0.160 and $\mathrm{p}$-value $=0.018$. The result of this study was consistent with the findings of the previous study of Jaworski, Ravichandran, Karpinski and Singh [18]. Therefore, hypothesis $\mathrm{H}_{4}$ was supported.

For hypothesis 5, the research found that innovativeness had a positive impact on affective commitment with a standardized coefficient of 0.225 and p-value $=0.000$, which was consistent with the findings of the previous study of Inanlou and Ahn [6]. Therefore, hypothesis $\mathrm{H}_{5}$ was supported. 
For hypothesis 6, the research found that empowerment had a positive impact on affective commitment with a standardized coefficient of 0.138 and $\mathrm{p}$-value $=0.038$. Hofstede [32] stated that the countries are different in terms of the degree to which employees perceive that power is equally distributed between boss and subordinate. He labeled this cultural value as "power distance". In low power distance culture, a boss and a subordinate are quite equal in power status. It is also socially acceptable for subordinates to question the decisions made by the superior. However, in high power distance culture, less powerful people tend to accept that the power is distributed unequally. In this type of culture, subordinates tend to pay more respect to the superior and are willing to abide by a decision and follow orders made by the superior. Therefore, in high power distance culture, employees tended to be uncomfortable when they have to make decisions by themselves because they normally get used to the way of following orders. According to HofstedeInsights [33], "Vietnam scores high on this dimension (score of 70) which means that people accept a hierarchical order in which everybody has a place and which needs no further justification”. This means that employees tend to be uncomfortable when they have to make decisions by themselves because they normally get used to the way of following orders. However, this study showed the opposite result with the finding of Hofstede-Insights [33]. There was a positive relationship between empowerment and affective commitment of employees in this research. In order to explain this phenomenon, the authors state that this is appropriate to the practice in the company specializing in information technology, telecommunications. In Telecom companies, much of the work requires effort to learn new knowledge and propose new ideas to solve problems that help improve work efficiency, so the empowerment element in the job plays an essential role in creating a breakthrough in work. Thus, this is one of the peculiarities of organization culture to keep the people who are capable, always want the work done creatively. The result of this study was consistent with the findings of the previous study of Hanaysha [16]. Therefore, hypothesis $\mathrm{H}_{6}$ was supported.

\subsection{Control Variables}

For control variables, as shown in Figure 2 and Table 3, the differences between the mean were not statistically significant because the significance level of control variables such as gender (0.893), age (0.751), Degree (0.889), income (0.684), Experience (0.838), and Rank (0.324) was greater than 0.05, there was no statistically significant on the relationship between control variables and employee commitment.

\subsection{Model Fit}

Giao, et al. [34] recommended that the quality of a PLS model should be assessed by $\mathrm{R}^{2}$ value. They highlighted $\mathrm{R}^{2}$ value of above 0.26 for a larger effect, ranging from 0.13 to 0.26 for a medium effect, and under 0.02 for a small effect. In this research, the $\mathrm{R}^{2}$ coefficient of affective commitment was 0.448 . It was greater than 0.26 . Thus, it had a larger effect on the model.

\section{Conclusion and Recommendations}

\subsection{Conclusion}

The purpose of this study was to examine the relationship between organizational culture and organizational commitment (OC). Also, this research tested the impact of each dimension of organizational culture on OC to check among six dimensions of organizational culture. The finding of this study revealed that there were six components of organizational culture impacting on organizational commitment such as Innovativeness $\left(\beta_{5}=0.235\right)$, Teamwork $\left(\beta_{2}=0.205\right)$, Training and Development $\left(\beta_{3}=0.168\right)$, Reward and Recognition $\left(\beta_{4}=0.166\right)$, Organizational Communication $\left(\beta_{1}=0.162\right)$ and Empowerment $\left(\beta_{6}=0.134\right)$.

\subsection{Managerial Recommendations}

The results of this research study lead to many practical suggestions for both practitioners and managers of organizations desirous of improving organizational commitment.

First of all, telecom companies should focus on encouraging employee innovation, creativity. Of course, when applying a new way of working or a new idea to the job, some of the risks will appear to make the project undue, so companies need to consider encouraging innovation at the time and in the group. Besides, to enhance creativity in the work, the company does not just stop at the incentive to encourage employees to develop new ideas, but also to improve the process of creating the environment for employees to reach out to suggest innovative ideas.

Second, telecom companies need to focus on improving the efficiency of teamwork by teaming its staff not only within the same department but also by expanding the collaboration between departments in the company. However, the rate of individual and 
collective outcomes should be considered appropriate for each specific group in order to best promote personal and collective capacity, to avoid dependence, or dissatisfaction due to the noncooperation of some individuals that affect the outcome of the group.

Third, to improve the efficiency of training staff development should be focused on implementing employee skill enhancement courses, companies should consider evaluating the effectiveness of their courses on current employee performance through an annual survey of all employees. Besides, telecom companies should send employees abroad to improve their skills is essential in the long-term development strategy of the company, which will shorten the gap in the capacity of IT staff in the country than foreign companies, creating a competitive advantage for businesses in the international work environment, confirming IT-telecom employees are considered the property of the company.

Fourth, in order to retain talents, managers need to make reasonable and attractive income levels with their capabilities. The compensation should be based on the work performed by an employee to reflect the individual's ability, the fairness of the job and the complexity of the job as well as the titles and positions. Managers need to clearly and concretely define the achieved salary conditions, the level of rewards, and most importantly, always create the most favorable conditions and opportunities for all employees to strive for.

Fifth, the company should promote the exchange of information that helps each other, between departments, to facilitate the completion of the work of the organization. Moreover, two-way communication between the supervisor and the subordinate is equally important. Managers should create policies to help their employees work well with employees of each department, and other team members to complete the project in the best way.

Finally, managers should create a positive work environment in which employees are given authorization at an exceptional level of personal freedom and flexibility to have full performance success. Moreover, managers should give their employees encouragement to point out problems and suggest solutions. That is the way to empower them, and through that, the employees' decisions broaden the opportunity for empowered behavior. Some more suggestions for management are to organize more activities regarding empowerment to provide employees with more directions and to approach of effective application in organizations. Finally, managers could change and encourage employee empowerment by reallocating organizational resources to ensure balanced empowerment throughout organizational hierarchy; Training and coaching employees to aware of efficiency from empowerment in the working environment; Ensuring that all employees from different departments being trained with full of knowledge, skills to complete works with high self-confidence; Restructuring organizational culture to generate empowerment friendly environment; Updating regulations, instructions to encourage empowerment practices with special and direct attention.

\section{Limitations and Further Directions}

There are several limitations that should be taken into account when interpreting the result in this research. The first limitation is that the survey was done in 27 telecom companies in Vietnam by convenience sampling method. These respondents may not present for all employees in telecom companies in Vietnam. Thus, generalizability is still a major of this study. For future research, instead of using a convenience sampling method to collect data, probability sampling method should be used to improve the reliability of the results. The second limitation is the research just measures the influence of organizational culture on organizational commitment in general and did not consider the impact of groups of employees (e.g., hardware, software, computer networks) on this relationship. In further research, the impact of these variables should be implemented in order to have a full. Finally, the research only focused on affective commitment measuring organizational commitment. Thus, further study should consider organizational commitment on three-dimensions such as affective commitment, continuance commitment, and normative commitment.

\section{References:}

[1] Memari, N., et al. The Impact of Organizational Commitment Employees on Job Performance. A Study of Meli Bank. Interdiscipline Journal of Contemporary Research in Business 2013, 5, 164-171.

[2] Boon, O.K.; Arumugam, V. The influence of corporate culture on organizational commitment: Case study of semiconductor organization in Malaysia. Sunway Academic Journal 2006, 3, 99-115.

[3] Khan, T.I., et al. Job Involvement as Predictor of Employee Commitment: Evidence from Pakistan. International Journal of Business and Management 2011, 6, 252-262. 
[4] Pettegrew, A.M. On Studying Organizational Cultures. Administrative Science Quarterly 1979, 4, 570-581.

[5] Schein, E.H. Organizational Culture and Leadership; Jossey-Bass: San Francisco, 2004.

[6] Inanlou, Z.; Ahn, J.Y. The Effect Of Organizational Culture On Employee Commitment: A Mediating Role Of Human Resource Development In Korean Firms. The Journal of Applied Business Research 2017, 33, 87-94.

[7] Wallach, E.J. Individuals and organizations: The cultural match. Training \& Development Journal 1983, 37, 28-36.

[8] Ricardo, R.; Jolly, J. Organizational culture and teams. SAM Advanced Management Journal 1997, 62, 4-7.

[9] Porter, L.W., et al. Organizational commitment, job satisfaction, and turnover among psychiatric technicians. Journal of Applied Psychology 1974, 59, 603-609.

[10] Bateman, T.S.; Strasser, S. A longitudinal analysis of the antecedents of organizational commitment. Academy of Management journal 1984, 27, 95-112.

[11] Meyer, J.P.; Allen, N.J. Commitment in the Workplace: Theory, Research, and Application; Sage Publications: Thousand Oaks, 1997.

[12] Meyer, J.P., et al. Affective, Continuance, and Normative Commitment to the Organization: A Meta-analysis of Antecedents, Correlates, and Consequences. Journal of Vocational Behavior 2002, 61, 20-52.

[13] Dwyer, B. Creating Tomorrow's Catholic School: A Challenge to the Imagination; Catholic Education Office: Parramatta, 2005.

[14] Marchalina, L.; Ahmad, H. The Effect of Internal Communication on Employees' Commitment to Change in Malaysian Large Companies. Business Management and Strategy 2017, 8, 1-17.

[15] Scarnati, J.T. On becoming a team player. Team Performance Management An International Journal 2001, 7, 5-10.

[16] Hanaysha, J. Examining the Effects of Employee Empowerment, Teamwork, and Employee Training on Organizational Commitment. Procedia - Social and Behavioral Sciences 2016, 229, 298-306.

[17] Bulut, C.; Culha, O. The effects of organizational training on organizational commitment. International Journal of Training and Development 2010, 14, 309-332.

[18] Jaworski, C., et al. The effects of training satisfaction, employee benefits, and incentives on part-time employees' commitment. International Journal of Hospitality Management 2018, 74, 1-12.

[19] Juran, J.M.; Gryna, E.M. Quality planning and analysis (3rd ed.); McGraw-Hill: New York, 1993.

[20] Joinson, C. Reward your best employees. HRMagazine 1996, 4, 49-55.

[21] Vuong, B.N. Ảnh hưởng của các yếu tố chất lượng cuộc sống nơi làm việc đến sự gắn kết với tổ chức của nhân viên ngân hàng thương mại cổ phần Á Châu tại TP. HCM. Huflit Journal of Science 2017, 4, 37-47.

[22] West, M.A.; Farr, J.L. Innovation at Work: Psychological Perspectives. Social Behavior 1989, 4, 15-30.

[23] Grant, A.M.; Berry, J.W. The necessity of others is the mother of invention: intrinsic and prosocial motivations, perspective taking, and creativity. Academy of Management Journal 2011, 54, 73-96.

[24] Vuong, B.N.; Suntrayuth, S. The impact of human resource management practices on employee engagement and moderating role of gender and marital status: An evidence from the Vietnamese banking industry. Management Science Letters 2020, 10, 1633-1648, doi:10.5267/j.msl.2019.12.003.

[25] Page, N.; Czuba, C.E. Empowerment: What it is? Journal of Extension 1999, 37, 1-7.

[26] Giao, H.N.K.; Vương, B.N. Ảnh hưởng của các yếu tố văn hóa doanh nghiệp đến sự gắn bó của nhân viên với tổ chức tại Công ty $\mathrm{CP}$ CMC Telecom Thành Phố Hồ Chí Minh. Tạp chí Kinh tế - Kỹ thuật 2016, 13, 87-101.

[27] Denison, D.R.; Mishra, A.H. Toward a Theory of Organizational Culture and Effectiveness. Organizational Science 1995, 6, 204-223.

[28] Giao, H.N.K.; Vuong, B.N. Giáo trình cao học phuơng pháp nghiên cúu khoa học trong kinh doanh cập nhật SmartPLS; Nhà Xuất Bản Tài Chính: TP. Hồ Chí Minh, 2019.

[29] Vuong, B.N., et al. An empirical analysis of mobile banking adoption in Vietnam. Management \& Society Electronic Journal 2020, 14, 3365-3393 doi:10.21171/ges.v14i37.3078.

[30] Giao, H.N.K., et al. The influence of website quality on consumer's e-loyalty through the mediating role of e-trust and e-satisfaction: An evidence from online shopping in Vietnam. Uncertain Supply Chain Management 2020, 8, 351-370, doi:10.5257/j.uscm.2019.11.004.

[31] Vuong, B.N.; Giao, H.N.K. The impact of perceived brand globalness on consumers' 
purchase intention and the moderating role of consumer ethnocentrism: An evidence from Vietnam. Journal of International Consumer Marketing 2020, 32, 47-68, doi:10.1080/08961530.2019.1619115.

[32] Hofstede, G.H. The Cultural Relativity of Organizational Practices and Theories. Journal of International Business Studies 1983, 14, 7589.

[33] Hofstede-Insights. Country Comparison. Availabe online: www.hofstedeinsights.com/country-comparison (accessed on 23).

[34] Giao, H.N.K., et al. The Effect of Emotional Intelligence on Turnover Intention and the Moderating Role of Perceived Organizational Support: Evidence from the Banking Industry of Vietnam. Sustainability 2020, 12, 1857, doi:10.3390/su12051857. 